\title{
Methotrexate as combination partner of TNF inhibitors and tocilizumab. What is reasonable from an immunological viewpoint?
}

\author{
Torsten Witte
}

Received: 28 December 2014 / Accepted: 1 January 2015 / Published online: 22 January 2015

(C) The Author(s) 2015. This article is published with open access at Springerlink.com

\begin{abstract}
The goal of therapy of rheumatoid arthritis is to achieve a remission or at least low disease activity. TNF inhibitors induce high remission rates only in combination with methotrexate, whereas the efficacy of tocilizumab is optimal even as a monotherapy. In this article, the differing dependence of the biological drugs on methotrexate is explained from the viewpoint of an immunologist. A selective search and evaluation of the literature was performed with regard to the mode of action of TNF inhibitors, tocilizumab and methotrexate in rheumatoid arthritis. Methotrexate primarily inhibits the activation and proliferation of lymphocytes. TNF inhibitors suppress monocytes and myeloid dendritic cells, and tocilizumab has a broader activity and is directed against both the lymphoid as well as the myeloid compartment. In view of the broad mode of action of tocilizumab, it can be explained why this drug, in contrast to TNF inhibitors, is acting optimally even in monotherapy.
\end{abstract}

Keywords Cytokines and inflammatory mediators . Immunology $\cdot$ Rheumatic diseases $\cdot$ Rheumatoid arthritis (RA) $\cdot$ Specialty fields $\cdot$ Tissues or models

\section{Background}

Since the introduction of biologics into the treatment of rheumatoid arthritis (RA), patients' symptoms have been significantly reduced and the process of joint destruction markedly decelerated. At present, about $15 \%$ of RA patients in

T. Witte $(\bowtie)$

Clinic for Immunology and Rheumatology, Medical University of

Hannover, Carl-Neuberg-Str. 1, 30625 Hannover, Germany

e-mail: Witte.Torsten@mh-hannover.de
Germany are treated with biologics. Five TNF inhibitors, together with tocilizumab and abatacept, are approved for use as first-line biologics following failure of at least one or two conventional disease-modifying anti-rheumatic drugs (DMARDs). Earlier studies, e.g. the TEMPO trial for etanercept [1] and the PREMIER trial for adalimumab [2], showed that the TNF inhibitors in monotherapy are much less effective than in combination with methotrexate. In contrast, two studies (Charisma [3] and ACT-RAY [4]) demonstrated for tocilizumab monotherapy near equivalence to similar efficacy compared to tocilizumab in combination with methotrexate. In the Adalimumab Actemra (ADACTA) trial, adalimumab and tocilizumab were compared in RA patients intolerant of methotrexate [5]. Tocilizumab was significantly superior to adalimumab as assessed by various outcome parameters, including ACR20 response and reduction of DAS28, CDAI and SDAI. In contrast to tocilizumab, TNF inhibitors require combination therapy with methotrexate for full effect. This article provides an overview of studies on the mode of action of TNF inhibitors, tocilizumab and methotrexate, and offers an explanation for the divergent dependency of TNF inhibitors and tocilizumab on the combination with methotrexate.

Pathophysiology of rheumatoid arthritis

The initiation of RA is facilitated by a genetic predisposition. In addition, the probability of developing RA is influenced by environmental factors such as smoking, alcohol and nutrition. The autoimmune aspect of the disease begins many years before overt arthritis occurs. In this 'pre-arthritis' phase, the autoantibodies rheumatoid factor (RF) and anti-citrullinated peptide/protein antibodies (ACPA) can usually be detected [6]; however, even on biopsy, no inflammatory changes can be found in the joint [7]. At present, it remains unclear where 
the location of this pre-arthritis stage is. Candidates include the respiratory system (since RA affects mainly smokers) and the lymph nodes.

The joint inflammation, which usually starts after a long period of pre-arthritis, has three main phases:

\section{Adhesion and migration}

At the initiation of arthritis, cells of the immune system move into the joints. Arthritis is probably triggered by an autoantigen in the joint. This autoantigen has not yet been identified, and triggers are likely to vary from patient to patient. Initially, antigen-presenting cells in the joint loaded with an autoantigen probably move to the central lymphatic organs and activate T cells there. They then migrate back to the joints, along with circulating immune cells.

\section{Activation/inflammation}

Most of the lymphocytes in the synovial membrane comprise $\mathrm{CD}^{+}$T-helper cells that are mainly part of the Th1 and proinflammatory Th17 subsets $[8,9]$. B cells and macrophages are also present, as well as large numbers of neutrophil granulocytes in the synovial fluid.

The cells of the immune system interact in the inflamed joint and activate each other by cell-cell contact as well as by the production of cytokines. The formation of cytokines such as TNF- $\alpha$ and IL- 6 at the site of inflammation leads to activation of the endothelium cells in newly formed vessels and to an increase in adhesion receptors such as intercellular adhesion molecule 1 (ICAM-1) and vascular cell adhesion molecule 1 (VCAM-1) [10]. This further increases the adhesion and finally migration of leucocytes and lymphocytes from the blood into the inflamed joints [11].

\section{Destruction of the joint}

Fibroblast-like synovial cells are activated and produce collagenases (such as MMP-1, MMP-3 and MMP-13), which attack the cartilage [12]. Then, an inflammatory pannus forms, in which $\mathrm{T}$ and $\mathrm{B}$ lymphocytes, macrophages and dendritic cells can be identified. The inflammatory tissue invades deeper into the cartilage and finally the bone. Cytokines formed in the ongoing inflammation, such as IL- 6 and TNF- $\alpha$, activate chondro- and osteoclasts and thus further contribute to the disintegration of bone and cartilage. Activated T cells and IL-18-stimulated macrophages produce receptor activator of nuclear factor kappa-B ligand (RANK-L), a substance that also activates osteoclasts and promotes the disintegration of bone. The inflamed tissue activates angioneogenesis with factors such as vascular endothelial growth factor (VEGF), prostaglandins, IL-8, ENA-78 or angiopoietin-1 $[13,14]$ in order to be sufficiently supplied with blood. In spite of the active formation of new vessels, blood supply to the inflammatory tissue is critical, and the $\mathrm{pO}_{2}$ in the synovial fluid is always markedly below that in the blood. Angioneogenesis therefore is essential for the perpetuation of the inflammation [15].

Insights into the pathophysiology of RA have led to the development and use of biologics. The mode of action of classical DMARDs, and specifically that of methotrexate, can now be at least partially explained.

\section{Mode of action of methotrexate}

Methotrexate (MTX) was first used in the treatment of RA in 1951 [16], but has only been widely prescribed since the 1980s. Methotrexate is a folic acid antagonist which reduces the concentration of intracellular folinic acid needed for purine and pyrimidine metabolism as well as for amino acid synthesis. Methotrexate therefore has an anti-proliferative effect. Based on recent studies, methotrexate also increases the extracellular concentration of the anti-inflammatory molecule adenosine by dephosphorylation of adenine nucleotides, and therefore has an anti-inflammatory effect in addition to its anti-proliferative action.

\section{Activation/inflammation}

In patients with RA, methotrexate inhibits the proliferation of cells and induces apoptosis (cell death) of activated cells. Both mechanisms mainly affect the lymphocytes and also, to a lesser degree, monocytes [17]. Methotrexate therefore reduces the number of activated T lymphocytes (Fig. 1). The expression of adhesion molecules such as ICAM-1 on T lymphocytes is reduced, as well as the production of the cytokines IL-6, TNF- $\alpha$ and GM-CSF by T lymphocytes [18]. The concentration of rheumatoid factor is also reduced in the process. In contrast to its effect on $\mathrm{T}$ lymphocytes, methotrexate does not substantially influence the cytokine production of monocytes [18].

Methotrexate probably reduces the interaction of $\mathrm{T}$ lymphocytes and synovial fibroblasts by reduced cytokine production, e.g. of IL-6, IL-15 and IL-17 [19]. On monocytes, the expression of $\mathrm{Fc}$ receptors I and II (CD64 and CD32) is decreased, so that the capacity of the monocytes to be activated by circulating immune complexes is reduced [20].

\section{Destruction of the joint}

The production of RANK-L by synovial fibroblasts is decreased and that of osteoprotegerin is increased [21]. Both mechanisms reduce the differentiation of osteoclasts and, as a consequence, the amount of bone destruction. Methotrexate also reduces the concentration of MMP-1 and MMP-3 and 
Fig. 1 Immunological targets of methotrexate

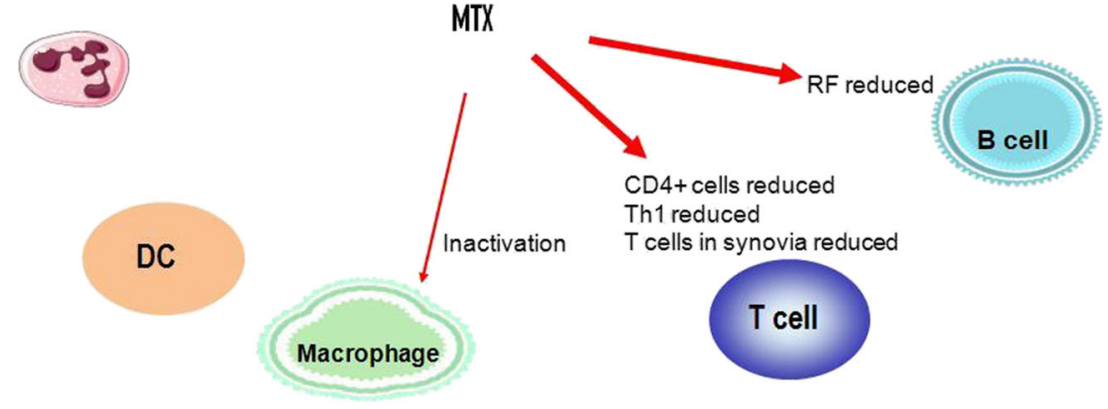

thus could contribute to the preservation of the joint cartilage. In contrast, angioneogenesis does not appear to be influenced [22].

\section{Mode of action of the TNF inhibitors}

As described above, TNF- $\alpha$ is one of the dominant cytokines in the pathogenesis of RA. TNF- $\alpha$ is predominantly produced by monocytes/macrophages, as well as by $\mathrm{T}$ cells, and activates, for example, macrophages and endothelial cells, after binding to the TNF receptor (CD120), which is expressed on multiple cells. As a consequence, there is an increase in the production of IL-1, IL-6 and other proinflammatory cytokines. Due to the important role of TNF- $\alpha$ in the pathophysiology of RA, TNF inhibitors are used in therapy. Infliximab is a chimaeric antibody targeted at TNF- $\alpha$. Today, complete human antibodies against TNF- $\alpha$ are available in the form of adalimumab and golimumab, while certolizumab is a pegylated human anti-TNF- $\alpha$ antibody (which does not bind to Fc receptors); etanercept is a soluble TNF receptor. Everyday clinical experience shows that some RA patients respond to a second, but not the first, TNF blocker. Therefore, there may be subtle differences in the modes of action of the individual TNF inhibitors, which will not be discussed here in general, however.

TNF inhibitors influence the pathophysiology of RA on several levels.

\section{Adhesion/migration}

At least in vitro, TNF inhibitors reduce the expression of VCAM on endothelial cells from the microvasculature of the intestine [23] and thereby reduce the ability of leucocytes to migrate from the blood into the inflamed tissue via adhesion to the vessel walls.

\section{Activation}

The degree of activation of the monocytes is markedly reduced $[24,25]$. In the synovial fluid, the number of neutrophil granulocytes and myeloid dendritic cells ( $\mathrm{mDCs}$ ) is reduced during TNF inhibition (Fig. 2).

The influence on lymphocytes is less pronounced. In vitro studies have shown that infliximab is able to induce apoptosis (programmed cell death) at least in some $\mathrm{T}$ lymphocytes. In vivo, however, both infliximab and etanercept were able to trigger apoptosis only in monocytes, but not in lymphocytes [26]. The activity of CD4+ CD25+-regulatory $\mathrm{T}$ cells which are involved in the protection from autoimmune disease is also unaffected [27]. The subpopulations of the B lymphocytes are generally not affected by TNF inhibitors. The number of memory B lymphocytes was increased only in the subset of RFnegative RA patients [28].

The change in cell populations affects the production of cytokines in the blood. Specifically, the concentration of proinflammatory cytokines produced by monocytes, such as IL6, MIP-1 and CCL20 [29], is reduced during treatment with TNF inhibitors. The concentration of cytokines produced by $\mathrm{T}$ cells, however, does not change [29].

\section{Joint destruction}

TNF inhibitors decelerate joint destruction even if the inflammation does not improve. TNF inhibitors reduce the production of MMPs (such as MMP-1, MMP-3, MMP-9) that contribute to the chondroclast activation and cartilage destruction [30]. Furthermore, the production of RANK-L and osteoprotegerin (involved with the osteoclast activation and bone destruction) is reduced [21,31]. The production of VEGF, stimulating angiogenesis required for the blood supply of the pannus tissue, is also reduced [32, 33].

\section{Mode of action of tocilizumab}

Tocilizumab binds both to the membrane-bound and soluble IL-6 receptor and can thus completely interrupt the effect of IL-6. IL-6 is a proinflammatory cytokine that binds to the IL-6 receptor and then to gp130, a signal transduction molecule. The membrane-bound IL-6 receptor is only expressed on few 
Fig. 2 Immunological targets of TNF inhibitors

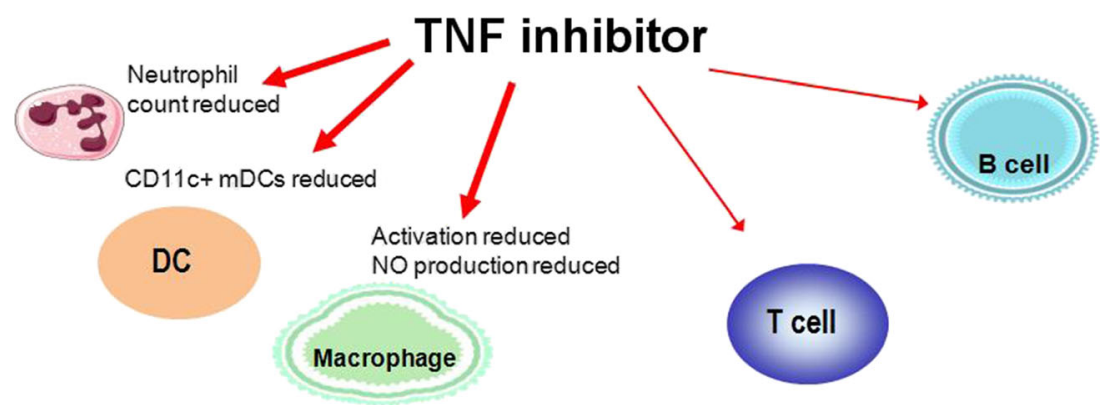

cell types. However, the soluble IL-6 receptor circulates in the blood and binds to IL-6. This complex can bind to gp130, which is expressed on the surface of most cells (trans-signalling). IL-6 therefore has a widespread effect on many cells and functions. In the inflammatory process, IL- 6 increases the production of chemokines and expression of adhesion molecules on lymphocytes [34]. The production of chemokines (such as MCP-1, IL-8) is also increased in endothelial cells, rheumatoid arthritis fibroblast-like synoviocytes (RA-FLS) and mononuclear cells $[35,36]$, as is the synthesis of RANK-L by RA-FLS, and that of MMP-1, MMP-3 and MMP-13 in chondrocytes [37].

The costimulation of naïve T cells with IL-6 is key to their differentiation into proinflammatory Th17 cells, which play an important role in the pathophysiology of RA. IL-6 was originally identified as a differentiation factor of B cells and is involved in the development of plasma cells [38]. IL-6 also acts on plasmablasts and additionally induces the IL-21 production of CD4+ T cells [39], which in turn increases the proliferation of B cells.

\section{Activation}

Tocilizumab has a particularly marked effect on the B cells. A reduction in the number of memory $B$ cells $[40,41]$ has been seen in patients with RA and systemic lupus erythematosus (SLE), along with reductions in plasma cells [42] and increases of the number of regulatory B cells [43] that can interrupt immune reactions (Fig. 3). The number of B cells in the inflamed synovial membrane is reduced [44]. Tocilizumab can recover the $\mathrm{T}$ cell balance in RA patients as it reduces the number of Th17 cells and increases the ratio of regulatory $\mathrm{T}$ cells [45]. The concentration of the proinflammatory cytokines [29] produced by the T cells is also reduced. Tocilizumab not only acts on lymphocytes but also reduces the number of monocytes and myeloid dendritic cells in the peripheral blood of RA patients [46]. Additionally, the number of neutrophil granulocytes, which represent the majority of cells in the synovial fluid, is markedly reduced, at least in the peripheral blood.

\section{Joint destruction}

Treatment with tocilizumab reduces VEGF and RANK-L production [47] by RA-FLS and thus angiogenesis and activation of osteoclasts. A reduction in RANK-L has been shown to increase the number of osteoblasts and reduce that of the osteoclasts in a monkey model [48].

A comparison of tocilizumab responders and nonresponders showed that the concentration of macrophage migration inhibitory factor (MIF), tumour necrosis factor-like weak inducer of apoptosis (TWEAK) and " $\mathrm{C}$ $\mathrm{X}-\mathrm{C}$ motif chemokine 10" (CXCL10) was reduced in responders [49]. MIF is produced by monocytes and $\mathrm{T}$ cells alike and is involved in the perpetuation of synovitis and destruction. During therapy with tocilizumab, proinflammatory cytokines such as IL-1 and IL-2 produced by T cells and TNF- $\alpha$ produced by monocytes are also reduced.

According to current insights, tocilizumab therefore has a very broad effect and regulates $\mathrm{B}$ and $\mathrm{T}$ lymphocytes, as well as the monocytes and dendritic cells.
Fig. 3 Immunological targets of tocilizumab

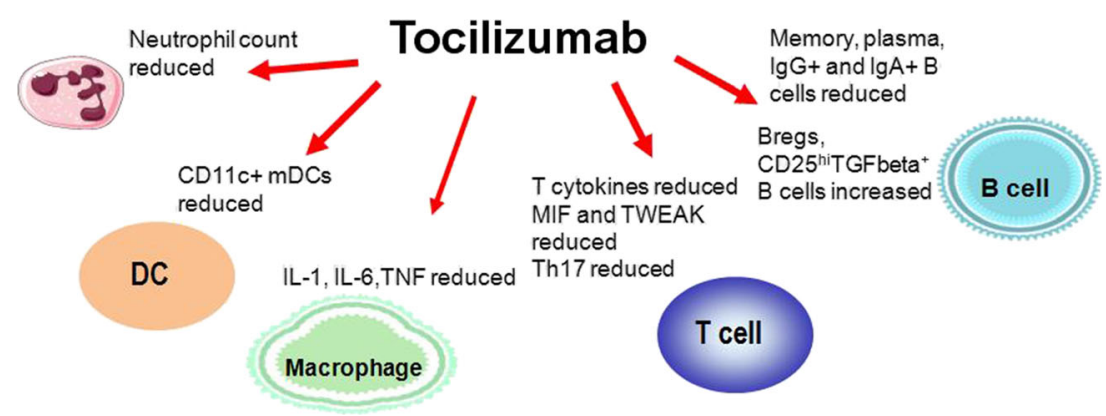




\section{Implications for practice}

- TNF inhibitors, whose mode of action (MoA) primarily targets monocytes and dendritic cells, and MTX, which inhibits lymphocytes, exert a synergistic therapeutic effect in RA.

- Tocilizumab has a broader effect than TNF inhibitors and mainly targets $\mathrm{T}$ and $\mathrm{B}$ lymphocytes, but also dendritic cells and monocytes.

- The combination of TNF inhibitors with methotrexate fills the gap of each substance with regard to the MoA, while tocilizumab alone has a very broad effect.

- The observation from studies, which show that tocilizumab monotherapy is as effective as tocilizumab in combination with methotrexate, is therefore not surprising.

Disclosures The author has received honoraria from the companies Chugai Pharma Ltd, AbbVie Germany, Pfizer, Roche Pharma, UCB Pharma and MSD.

Open Access This article is distributed under the terms of the Creative Commons Attribution License which permits any use, distribution, and reproduction in any medium, provided the original author(s) and the source are credited.

\section{References}

1. van der Heijde D, Klareskog L, Rodriguez-Valverde V, Codreanu C, Bolosiu H, Melo-Gomes J, Tornero-Molina J, Wajdula J, Pedersen R, Fatenejad S, TEMPO Study Investigators (2006) Comparison of etanercept and methotrexate, alone and combined, in the treatment of rheumatoid arthritis: two-year clinical and radiographic results from the TEMPO study, a double-blind, randomized trial. Arthritis Rheum 54:1063-1074

2. Breedveld FC, Weisman MH, Kavanaugh AF, Cohen SB, Pavelka K, van Vollenhoven R, Sharp J, Perez JL, Spencer-Green GT (2006) The PREMIER study: a multicenter, randomized, double-blind clinical trial of combination therapy with adalimumab plus methotrexate versus methotrexate alone or adalimumab alone in patients with early, aggressive rheumatoid arthritis who had not had previous methotrexate treatment. Arthr Rheum 54:26-37

3. Maini RN, Taylor PC, Szechinski J, Pavelka K, Bröll J, Balint G, Emery P, Raemen F, Petersen J, Smolen J, Thomson D, Kishimoto T, CHARISMA Study Group (2006) Double-blind randomized controlled clinical trial of the interleukin- 6 receptor antagonist, tocilizumab, in European patients with rheumatoid arthritis who had an incomplete response to methotrexate. Arthritis Rheum 54:2817-2829

4. Dougados M, Kissel K, Sheeran T, Tak PP, Conaghan PG, Mola EM, Schett G, Amital H, Navarro-Sarabia F, Hou A, Bernasconi C, Huizinga T (2013) Adding tocilizumab or switching to tocilizumab monotherapy in methotrexate inadequate responders: 24-week symptomatic and structural results of a 2-year randomised controlled strategy trial in rheumatoid arthritis (ACT-RAY). Ann Rheum Dis 72:4350

5. Gabay C, Emery P, van Vollenhoven R, Dikranian A, Alten R, Pavelka K, Klearman M, Musselman D, Agarwal S, Green J, Kavanaugh A, ADACTA Study Investigators (2013) Tocilizumab monotherapy versus adalimumab monotherapy for treatment of rheumatoid arthritis (ADACTA): a randomised, double-blind, controlled phase 4 trial. Lancet 381:1541-1550

6. Nielen MM, van Schaardenburg D, Reesink HW, van de Stadt RJ, van der Horst-Bruinsma IE, de Koning MH, Habibuw MR, Vandenbroucke JP, Dijkmans BA (2004) Specific autoantibodies precede the symptoms of rheumatoid arthritis: a study of serial measurements in blood donors. Arthritis Rheum 50:380-386

7. van de Sande MG, de Hair MJ, van der Leij C, Klarenbeek PL, Bos WH, Smith MD, Maas M, de Vries N, van Schaardenburg D, Dijkmans BA, Gerlag DM, Tak PP (2011) Different stages of rheumatoid arthritis: features of the synovium in the preclinical phase. Ann Rheum Dis 70:772-777

8. van der Voort R, van Lieshout AW, Toonen LW, Slöetjes AW, van den Berg WB, Figdor CG, Radstake TR, Adema GJ (2005) Elevated CXCL16 expression by synovial macrophages recruits memory $\mathrm{T}$ cells into rheumatoid joints. Arthritis Rheum 52:1381-1391

9. Shen H, Goodall JC, Hill Gaston JS (2009) Frequency and phenotype of peripheral blood Th17 cells in ankylosing spondylitis and rheumatoid arthritis. Arthritis Rheum 60:1647-1656

10. Gerritsen ME, Kelley KA, Ligon G, Perry CA, Shen CP, Szczepanski A, Carley WW (1993) Regulation of the expression of intercellular adhesion molecule 1 in cultured human endothelial cells derived from rheumatoid synovium. Arthritis Rheum 36:593-602

11. Lally F, Smith E, Filer A, Stone MA, Shaw JS, Nash GB, Buckley CD, Rainger GE (2005) A novel mechanism of neutrophil recruitment in a coculture model of the rheumatoid synovium. Arthritis Rheum 52:3460-3469

12. Wernicke D, Schulze-Westhoff C, Bräuer R, Petrow P, Zacher J, Gay $\mathrm{S}$, Gromnica-Ihle E (2002) Stimulation of collagenase 3 expression in synovial fibroblasts of patients with rheumatoid arthritis by contact with a three-dimensional collagen matrix or with normal cartilage when coimplanted in NOD/SCID mice. Arthritis Rheum 46:64-74

13. Koch AE, Volin MV, Woods JM, Kunkel SL, Connors MA, Harlow LA, Woodruff DC, Burdick MD, Strieter RM (2001) Regulation of angiogenesis by the C-X-C chemokines interleukin- 8 and epithelial neutrophil activating peptide 78 in the rheumatoid joint. Arthritis Rheum 44:31-40

14. Distler JH, Wenger RH, Gassmann M, Kurowska M, Hirth A, Gay S, Distler O (2004) Physiologic responses to hypoxia and implications for hypoxia-inducible factors in the pathogenesis of rheumatoid arthritis. Arthritis Rheum 50:10-23

15. Szekanecz Z, Besenyei T, Szentpétery A, Koch AE (2010) Angiogenesis and vasculogenesis in rheumatoid arthritis. Curr Opin Rheumatol 22:299-306

16. Gubner R, August S, Ginsberg V (1951) Therapeutic suppression of tissue reactivity. II. Effect of aminopterin in rheumatoid arthritis and psoriasis. Am J Med Sci 221:176

17. Herman S, Zurgil N, Deutsch M (2005) Low dose methotrexate induces apoptosis with reactive oxygen species involvement in $\mathrm{T}$ lymphocytic cell lines to a greater extent than in monocytic lines. Inflamm Res 54:273-280

18. Gerards AH, de Lathouder S, de Groot ER, Dijkmans BA, Aarden LA (2003) Inhibition of cytokine production by methotrexate. Studies in healthy volunteers and patients with rheumatoid arthritis. Rheumatology 42:1189-1196

19. Miranda-Carús ME, Balsa A, Benito-Miguel M, Pérez de Ayala C, Martín-Mola E (2004) IL-15 and the initiation of cell contactdependent synovial fibroblast-T lymphocyte cross-talk in rheumatoid arthritis: effect of methotrexate. J Immunol 173:1463-1476

20. Wijngaarden S, van Roon JA, van de Winkel JG, Bijlsma JW, Lafeber FP (2005) Down-regulation of activating Fcgamma receptors on monocytes of patients with rheumatoid arthritis upon methotrexate treatment. Rheumatology 44:729-734

21. Lee CK, Lee EY, Chung SM, Mun SH, Yoo B, Moon HB (2004) Effects of disease-modifying antirheumatic drugs and 
antiinflammatory cytokines on human osteoclastogenesis through interaction with receptor activator of nuclear factor kappaB, osteoprotegerin, and receptor activator of nuclear factor kappaB ligand. Arthritis Rheum 50:3831-3843

22. Fiehn C, Wunder A, Krienke S, Max R, Ho AD, Moehler T (2005) Lack of evidence for inhibition of angiogenesis as a central mechanism of the antiarthritic effect of methotrexate. Rheumatol Int 25: $108-113$

23. Danese S, Sans M, Scaldaferri F, Sgambato A, Rutella S, Cittadini A, Piqué JM, Panes J, Katz JA, Gasbarrini A, Fiocchi C (2006) TNFalpha blockade down-regulates the CD40/CD40L pathway in the mucosal microcirculation: a novel anti-inflammatory mechanism of infliximab in Crohn's disease. J Immunol 176:2617-2624

24. Perkins DJ, St Clair EW, Misukonis MA, Weinberg JB (1998) Reduction of NOS2 overexpression in rheumatoid arthritis patients treated with anti-tumor necrosis factor alpha monoclonal antibody (cA2). Arthritis Rheum 41:2205-2210

25. Pittoni V, Bombardieri M, Spinelli FR, Scrivo R, Alessandri C, Conti F, Spadaro A, Valesini G (2002) Anti-tumour necrosis factor (TNF) alpha treatment of rheumatoid arthritis (infliximab) selectively down regulates the production of interleukin (IL) 18 but not of IL12 and IL13. Ann Rheum Dis 61:723-725

26. Catrina AI, Trollmo C, af Klint E, Engstrom M, Lampa J, Hermansson Y, Klareskog L, Ulfgren AK (2005) Evidence that anti-tumor necrosis factor therapy with both etanercept and infliximab induces apoptosis in macrophages, but not lymphocytes, in rheumatoid arthritis joints: extended report. Arthritis Rheum 52: $61-72$

27. Oh JS, Kim YG, Lee SG, So MW, Choi SW, Lee CK, Yoo B (2013) The effect of various disease-modifying anti-rheumatic drugs on the suppressive function of CD4(+)CD25 (+) regulatory T cells. Rheumatol Int 33:381-388

28. Roll P, Muhammad K, Schumann M, Kleinert S, Tony HP (2012) RF positivity has substantial influence on the peripheral memory B-cell compartment and its modulation by TNF inhibition. Scand $\mathbf{J}$ Rheumatol 41:180-185

29. Yamana J, Iwahashi M, Kim M, Sasaki R, Kobayashi K, Yamana S et al (2011) T-cell-related cytokines are inhibited in response to tocilizumab in patients with rheumatoid arthritis in contrast with TNFinhibitor. [Abstract]. Arthritis Rheum 63(Suppl 10):51

30. Klimiuk PA, Sierakowski S, Domyslawska I, Chwiecko J (2004) Effect of repeated infliximab therapy on serum matrix metalloproteinases and tissue inhibitors of metalloproteinases in patients with rheumatoid arthritis. J Rheumatol 31:238-242

31. Catrina AI, af Klint E, Ernestam S, Catrina SB, Makrygiannakis D, Botusan IR, Klareskog L, Ulfgren AK (2006) Anti-tumor necrosis factor therapy increases synovial osteoprotegerin expression in rheumatoid arthritis. Arthritis Rheum 54:76-81

32. Kanbe K, Inoue K, Inoue Y, Suzuki Y (2008) Histological analysis of synovium in cases of effect attenuation associated with infliximab therapy in rheumatoid arthritis. Clin Rheumatol 27:777-781

33. Strunk J, Bundke E, Lange U (2006) Anti-TNF-alpha antibody Infliximab and glucocorticoids reduce serum vascular endothelial growth factor levels in patients with rheumatoid arthritis: a pilot study. Rheumatol Int 26:252-256

34. Romano M, Sironi M, Toniatti C, Polentarutti N, Fruscella P, Ghezzi P, Faggioni R, Luini W, van Hinsbergh V, Sozzani S, Bussolino F, Poli V, Ciliberto G, Mantovani A (1997) Role of IL-6 and its soluble receptor in induction of chemokines and leukocyte recruitment. Immunity 6:315-325
35. Suzuki M, Hashizume M, Yoshida H, Mihara M (2010) Antiinflammatory mechanism of tocilizumab, a humanized anti-IL-6R antibody: effect on the expression of chemokine and adhesion molecule. Rheumatol Int 30:309-315

36. Romano M, Sironi M, Toniatti C, Polentarutti N, Fruscella P, Ghezzi P, Faggioni R, Luini W, van Hinsbergh V, Sozzani S, Bussolino F, Poli V, Ciliberto G, Mantovani A (1997) Role of IL-6 and its soluble receptor in induction of chemokines and leukocyte recruitment. Immunity 6:315-325

37. Hashizume M, Mihara M (2011) The roles of interleukin-6 in the pathogenesis of rheumatoid arthritis. Arthritis 2011:765624

38. Muraguchi A, Hirano T, Tang B, Matsuda T, Horii Y, Nakajima K, Kishimoto T (1988) The essential role of B cell stimulatory factor 2 (BSF-2/IL-6) for the terminal differentiation of B cells. J Exp Med 167:332-344

39. Dienz O, Eaton SM, Bond JP, Neveu W, Moquin D, Noubade R, Briso EM, Charland C, Leonard WJ, Ciliberto G, Teuscher C, Haynes L, Rincon M (2009) The induction of antibody production by IL- 6 is indirectly mediated by IL- 21 produced by CD4+ T cells. J Exp Med 206:69-78

40. Roll P, Muhammad K, Schumann M, Kleinert S, Einsele H, Dörner T, Tony HP (2011) In vivo effects of the anti-interleukin-6 receptor inhibitor tocilizumab on the B cell compartment. Arthritis Rheum 63:1255-1264

41. Muhammad K, Roll P, Seibold T, Kleinert S, Einsele H, Dörner T, Tony HP (2011) Impact of IL-6 receptor inhibition on human memory $\mathrm{B}$ cells in vivo: impaired somatic hypermutation in preswitch memory B cells and modulation of mutational targeting in memory B cells. Ann Rheum Dis 70:1507-1510

42. Illei GG, Shirota Y, Yarboro CH, Daruwalla J, Tackey E, Takada K, Fleisher T, Balow JE, Lipsky PE (2010) Tocilizumab in systemic lupus erythematosus: data on safety, preliminary efficacy, and impact on circulating plasma cells from an open-label phase I dosageescalation study. Arthritis Rheum 62:542-552

43. Snir A, Kessel A, Haj T, Rosner I, Slobodin G, Toubi E (2011) AntiIL-6 receptor antibody (tocilizumab): a B cell targeting therapy. Clin Exp Rheumatol 29:697-700

44. Kanbe K, Chen Q, Nakamura A, Hobo K (2011) Inhibition of MAP kinase in synovium by treatment with tocilizumab in rheumatoid arthritis. Clin Rheumatol 30:1407-1413

45. Samson M, Audia S, Janikashvili N, Ciudad M, Trad M, Fraszczak J, Ornetti P, Maillefert JF, Miossec P, Bonnotte B (2012) Inhibition of IL-6 function corrects Th17/Treg imbalance in rheumatoid arthritis patients. Arthritis Rheum 64:2499-2503

46. Richez C, Barnetche T, Khoryati L, Duffau P, Kostine M, ContinBordes C, Blanco P, Schaeverbeke T (2012) Tocilizumab treatment decreases circulating myeloid dendritic cells and monocytes, 2 components of the myeloid lineage. J Rheumatol 39:1192-1197

47. Nakahara H, Song J, Sugimoto M, Hagihara K, Kishimoto T, Yoshizaki K, Nishimoto N (2003) Anti-interleukin-6 receptor antibody therapy reduces vascular endothelial growth factor production in rheumatoid arthritis. Arthritis Rheum 48:1521-1529

48. Kato A, Matsuo S, Takai H, Uchiyama Y, Mihara M, Suzuki M (2008) Early effects of tocilizumab on bone and bone marrow lesions in a collagen-induced arthritis monkey model. Exp Mol Pathol 84: 262-270

49. Kasama T, Wakabayashi K, Isozaki T, Furuya H, Yanai R, Ohtsuka K et al (2011) Differential regulation of serum cytokine profiles in patients with rheumatoid arthritis treated with tocilizumab: possible involvement of macrophage migration inhibitory factor. [Abstract]. Arthritis Rheum 63(Suppl 10) 